\section{DAB on Human Hepatocytes}

Charles S. Gilbert, Carolinas Medical Center

Neutrophil myeloperoxidase standard 3,3'-Diaminobenzidine Tetrahydrochioride (DAB) procedure:

When staining neutrophils, a cell suspension would be preferred, but a finely minced buffy coat can be used, if you thick section and locate the stained cells before thin sectioning. Staining should be carried out as soon as possible after fixation. The myeloperoxidase (MPO) activity falls off such that we process samples within 2-3 weeks of fixation.

Note that fixation is for 1 hour. Enzyme activity may be destroyed if tixed for longer periods.

Chemical inhibition of some peroxidatic enzymes is possible, but inhibition is not $100 \%$ specific or effective. Chemical inhibition works best when an inhibition step (inhibitor and buffer) occurs before staining with the DAB solution which also contains the inhibiting agent.

The literature shows that it is difficult to assess different peroxidatic enzymes when they are colocalized using cytochemical techniques.

Always be sure to include appropriate controls (i.e., a morphological control as well as cytochemical ones).

The DAB-stained cells are viewed without uranyl acetate-lead citrate (UALC) counterstaining, or with lead citrate (LC) staining only. Counterstains may confound the granule analysis.

We place our DAB incubation in the dark (in a cabinet).

This procedure stains neutrophil primary granules for myeloperoxidase activity $\left[0.01 \% \mathrm{H}_{2} \mathrm{O}_{2}\right]$.

Procedure:

1) $3 \%$. Glutaraldehyde in $0.1 \mathrm{M}$ Cacodylate Buffer, $\mathrm{pH} 7.35$ @ $40^{\circ} \mathrm{C}$ (on ice)
1 hour.

2) Rinse $\times 3$ in $0.1 \mathrm{M}$ Cacodylate Buffer $+7 \%$ Sucrose, $\mathrm{pH} 7.35$. Store overnight in rinse buffer.

3) Rinse $x 1$ in $D A B$ solution without $\mathrm{H}_{2} \mathrm{O}_{2}$.

4) $\mathrm{DAB}$ solution with $\mathrm{H}_{2} \mathrm{O}_{2}$ at room temperature 30 minutes. [Control: Use DAB solution without $\mathrm{H}_{2} \mathrm{O}_{2}$ for 30 minutes.]

5) Rinse $x 1$ in $0.05 \mathrm{M}$ Tris Buffer, $\mathrm{pH} 7.6$.

6) Rinse $x 2$ in $0.1 \mathrm{M}$ Cacodylate Buffer $+7 \%$ Sucrose, $\mathrm{pH} 7.35$.

7) $1 \% \mathrm{OsO}_{4}$ in $0.1 \mathrm{M}$ Cacodylate Buffer, $\mathrm{pH} 7.35$, at room temperature 1 hour.

8) Dehydrate and embed

\section{DAB solution:}

\section{Reagents:}

3,3'-Diaminobenzidine tetrahydrochloride $(4 \mathrm{HCl}) 5 \mathrm{mg}$.

$0.05 \mathrm{M}$ Tris Buffer $\mathrm{pH} 7.610 \mathrm{~mL}$.

$3 \% \mathrm{H}_{2} \mathrm{O}_{2} 33 \mu \mathrm{L}$.

$\mathrm{pH}$ should be in the range of 7.0-7.6. When the buffer is fresh it is around 7.3-7.4.

DAB solution with $10 \mathrm{mM} \mathrm{KCN}$ :

3,3'-Diaminobenzidine $4 \mathrm{HCl} 5 \mathrm{mg}$.

$0.05 \mathrm{M}$ Tris Buffer, $\mathrm{pH} 7.6$. with $10 \mathrm{mM} \mathrm{KCN} 10 \mathrm{~mL}$.

$3 \% \mathrm{H}_{2} \mathrm{O}_{2} 33 \mu \mathrm{L}$

$0.05 \mathrm{M}$ Tris buffer, $\mathrm{pH} 7.6$ :

Tris-(hydroxymethyl)-aminomethane [99.0-99.5\%] $6.06 \mathrm{gm}$.

make up to $1000 \mathrm{~mL}$ with distilled $\mathrm{H}_{2} \mathrm{O}$.

Adjust $\mathrm{pH}$ to 7.6 .

$3 \% \mathrm{H}_{2} \mathrm{O}_{2}$ (Working Solution):

$50 \% \mathrm{H}_{2} \mathrm{O}_{2}$ (Commercial Stock Solution) $\mathrm{X} \mathrm{mL}$.

$0.05 \mathrm{M}$ Tris Buffer, $\mathrm{pH} 7.6$ make up to $10 \mathrm{~mL}$.

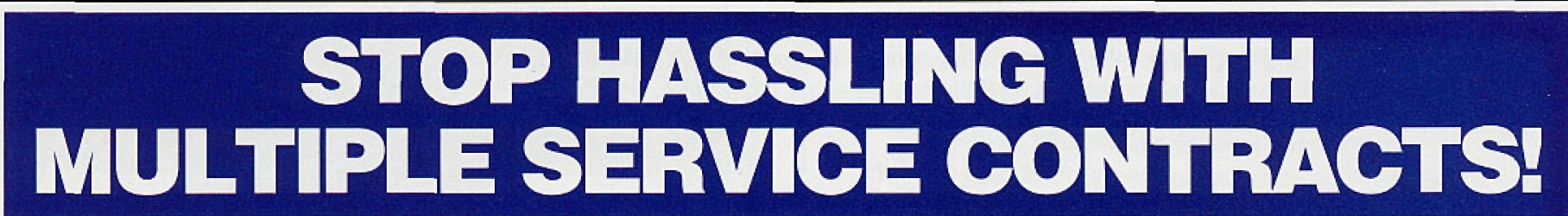

START by putting all of your instruments under one contract with MAS

(regardless of make or model). Our expert EM SERVICE GROUP has the knowledge and skill to keep your instrumentation working at its best.

\begin{tabular}{|c|c|c|}
\hline \multicolumn{2}{|c|}{ TEM'S/ SEM'S } & PREP EQUIPMENT \\
\hline $\begin{array}{c}\text { HITACHI } \\
\text { JEOL } \\
\text { AMRAY } \\
\text { CAMBRIDGE } \\
\text { We service all brand }\end{array}$ & $\begin{array}{c}\text { TOPCON } \\
\text { ISI } \\
\text { ZEISS } \\
\text { PHLIPS } \\
\text { under one contract. }\end{array}$ & $\begin{array}{c}\text { ULTRAMICROTOMES } \\
\text { DUPONT \& RMC } \\
\text { VACUUM COATERS } \\
\text { SPUTTER COATERS } \\
\text { MECHANICAL PUMPS } \\
\text { TURBO PUMPS } \\
\text { PLASMA ASHERS }\end{array}$ \\
\hline WE SERVICE & Contracts and On-Demand & \\
\hline COMPUTER CONTROLLERS & $\begin{array}{l}\text { Reasonable Rates from } \\
\text { Factory Trained Specialists. }\end{array}$ & \\
\hline BEAM BLANKERS & 1-800-421-8451 & \\
\hline WATER CHILLERS & $\begin{array}{r}3597 \text { Parkway Lane } \bullet \text { Suite } 250 \bullet \text { Norcro } \\
616 \text { Hutton Street } \\
\\
\text { Suite } 101 \cdot \text { Raleigh, } \\
\text { ADVANCED ANALY }\end{array}$ & 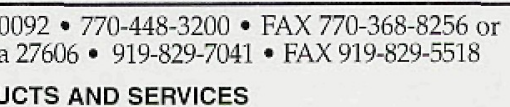 \\
\hline
\end{tabular}


See "Verification" section below to determine the value of " $X$ ".

Note: $3 \% \mathrm{H}_{2} \mathrm{O}_{2}$ working solutions should be made fresh before use using a concentrated stock solution which has been checked for the actual concentration. See the verification procedure for doing this spectrophotometrically.

$10 \mathrm{mM}$ potassium cyanide ( $\mathrm{KCN}$ ) [in $0.05 \mathrm{M}$ Tris Buffer, $\mathrm{pH} 7.6$ ]:

Potassium cyanide $65 \mathrm{mg}$.

Make up to $100 \mathrm{~mL}$ with $0.05 \mathrm{M}$ Tris Buffer, $\mathrm{pH} 7.6$

$\mathrm{pH}$ to 7.6 with $1 \mathrm{~N} \mathrm{HCl}$

\section{MODIFICATIONS:}

DAB with cyanide inhibition ( $10 \mathrm{mM} \mathrm{KCN}$ ):

This procedure inhibits cytochrome oxidase and myeloperoxidase. 4aminobenzhydrazide inhibits MPO.1,2,3-Aminotriazole inhibits catalase

For catalase localization use Tris buffer at $\mathrm{pH}$ 9.5-10.0.

For inhibition studies, always recheck the $\mathrm{pH}$ of the buffer-inhibitor solutions and $\mathrm{pH}$ them properly.

\section{References for peroxidase (DAB) staining:}

Angermuller, S. and H.D. Fahimi. 1981. Selective cytochemical localization of peroxidase, cytochrome oxidase and catalase In rat liver with $3,3^{\prime}$ diaminobenzidine. Histochemistry 71:33-44.

Biggar, W.D. and J.M. Sturgess. 1976. Peroxidase activity of alveolar macrophages. Lab. Invest. 34:31-42.

Breton-Gorius, J., Y. Coquin, and J. Guichard. 1978a. Cytochemical distinction between azurophils and catalase-containing granules in leukocytes. I. Studies in developing neutrophils and monocytes from patients with myeloperoxidase deficiency: Comparison with peroxidase-deficient chicken heterophils. Lab. Invest. 38:21-31.

Breton-Gorius, J. and J. Guichard. 1978b. Cytochemical distinction between azurophils and catalase-containing granules in leukocytes: Distribution in human promyelocytes and promonocytes. J. Reticuloendothelial Soc. 21:637-646.

Cotran, R.S. and M. Litt. 1970. Ultrastructural localization of horseradish peroxidase and endogenous peroxidase activity in guinea pig peritoneal macrophages. J. Immunol. 105:1536-1546.

Dunn, W.R., J. H. Hardin, S. S. Spicer. 1968. Ultrastructural localization of myeloperoxidase in human neutrophil and rabbit heterophil and eosinophil leukocytes. Blood 32:935-944.

Fahimi, H.D. 1969. Cytochemical localization of peroxidatic activity of catalase in rat hepatic microbodies (peroxisomes). J. Cell. Biol. 43:275-288.

Fahimi, H.D. 1979. An assessment of the DAB methods for cytochemical detection of catalase and peroxidase. J. Histochem. Cytochem. 27:13651366.

Graham, R.C., Jr. and M.J. Karnovsky. 1966. The early stages of absorption of injected horseradish peroxidase in the proximal tubules of mouse kidney: Ultrastructural cytochemistry by a new technique. J. Histochem. Cytochem. 14:291-302.

Kettle A. J., C.A.Gedye, M.B. Hampton, C.C. Winterbourn.1995, Inhibition of

myeloperoxidase by benzoic acid hydrazides. Biochem. J. 308:559-563.

Nishimura, E.T., G.M. Whest and H.Y. Yang. 1976. Ultrastructural localization of peroxidatic catalase in human peripheral blood leukocytes. Lab. Invest. 34:60-68

Novikoff, A.B. and S. Goldfischer. 1968. Visualization of microbodies for light and electron microscopy. Proc. Histochem. Soc. 16:507 (Abstract).

Novikoff, A.B. and S. Goldfischer. 1969. Visualization of peroxisomes (microbodies) and mitochondria with diaminobenzidene. J. Histochem. Cytochem. 17(10):675-680.

Novikoff, A.B.. P.M. Novikoff, N. Quintana, and D. Cleveland. 1972. Diffusion artifacts in 3,3'-diaminobenzidene cytochemistry. J. Histochem. Cytochem. 20:745-749.

Roels, F., E. Wisse, B. De Prest. and J. van der Meulen. 1975. Cytochemi- cal discrimination between catalases and peroxidases using diaminobenzidene. Histochemistry 41:281-312.

Zellmer, D.M. and W.A. Shannon Jr. 1983. Morphometric cytochemistry of catalase and myeloperoxidase-containing granules in the rabbit polymorphonuclear leukocyte. Histochem. J. 15:211-230.

Verification of $\left[\mathrm{H}_{2} \mathrm{O}_{2}\right]$ :

$E_{240}=43.6 \mathrm{~m}^{-1} \mathrm{~cm}^{-1}$ (extinction coefficient at wavelength 240)

$\mathrm{MW}=34.01 \mathrm{~g} / \mathrm{mole}$

$50 \% \mathrm{H}_{2} \mathrm{O}_{2}=1.2 \mathrm{~g} / \mathrm{mL}$ (density, rho)

Determine whether concentration is by weight or volume because serious $\mathrm{m} / \mathrm{scalculations}$ are possible.

Calculation for the molar concentration of:

$50 \%$ by $w t \Rightarrow(60 \mathrm{~g}) / 120 \mathrm{~g}=(60 \mathrm{~g}) / 100 \mathrm{~mL}$

$(60 \mathrm{~g}) / 100 \mathrm{~mL} \times 1 /(34.01 \mathrm{~g} / \mathrm{mole})=(1.761 \mathrm{~mole}) / 100 \mathrm{~mL} \Rightarrow 17.61 \mathrm{M}$

Stock solution must be diluted to measure the Absorbance $\left(A_{240}\right)$

$\mathrm{I}=$ length of light path in $\mathrm{cm}$

$\mathrm{C}=$ concentration (moles/liter)

$A_{240}=E_{240} \mid C \Rightarrow C=\left[A_{240} /\left(E_{240} \mid\right)\right] \times$ dilution factor

e.g. dilution of $1 / 1000 \mathrm{~A}_{240}=0.6375 \Rightarrow 14.6 \mathrm{M}$

$(14.6 \mathrm{MxMW}) / 10=(49.6 \mathrm{~g}) / 100 \mathrm{~mL}=(49.6 \mathrm{~g}) / 120 \mathrm{~g} \Rightarrow 41.4 \%$

Use this percentage in making up the $3 \% \mathrm{H}_{2} \mathrm{O}_{2}$ working solution.

Since the $50 \% \mathrm{H}_{2} \mathrm{O}_{2}(17.61 \mathrm{M})$ was actually $41.4 \%$ (14.6 M) it follows that:

$V_{1} C_{1}=V_{2} C_{2} \Rightarrow 14.6 \times=1.06(10 \mathrm{~mL}) \Rightarrow x \mathrm{ml}=10.6 / 14.6=0.728 \mathrm{~mL}$ Use $0.726 \mathrm{~mL}$ in making the $3 \% \mathrm{H}_{2} \mathrm{O}_{2}$ working solution.

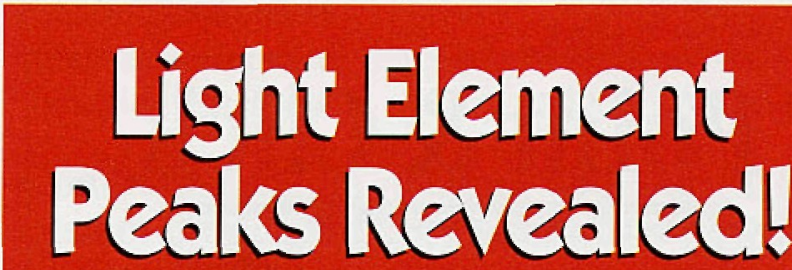

\section{Oil Film on EDX Windows Removed:}

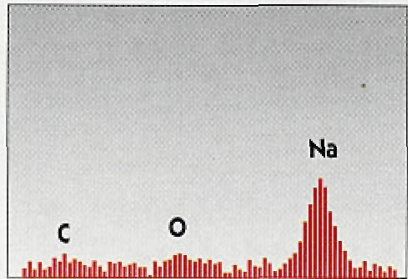

Oily Window

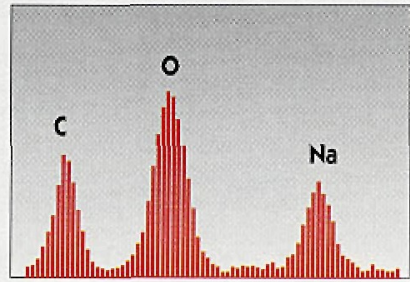

Clean Window
Oil build-up on EDX detector windows can ruin sensitivity for light element X-rays in SEMs. To stop oil condensation and keep the system clean, smart SEM users rely on the XEI Scientific SEM-CLEAN ${ }^{\top M}$ system.

Result: Consistent light element X-ray results and contaminationfree pictures. The Nitrogen purge of the inexpensive SEM-CLEAN system actively cleans your electron microscope while you're away.

\section{SEM-CLEAN"' Stops the Oil}

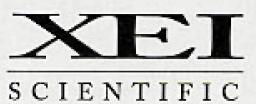

3124 Wessex Way, Redwood City, CA 94061-1348 650-369-0133 * Fax 650-363-1659

http://www.msa.microscopy.com/SM/XEI/XEIHomePage.html 